\title{
Bone Marrow Stem Cell with Some Commitment to Monocytic Differentiation
}

National Cancer Institute

\section{Source}

National Cancer Institute. Bone Marrow Stem Cell with Some Commitment to Monocytic

Differentiation. NCI Thesaurus. Code C42780.

A primitive, undifferentiated blood cell which can undergo division and tends to give rise to a blood cell of the monocyte lineage. 